\title{
Giant axonal neuropathy
}

\section{A clinicoradiopathologic diagnosis}

\section{Figure 1 Hair and MRI brain changes in giant axonal neuropathy}
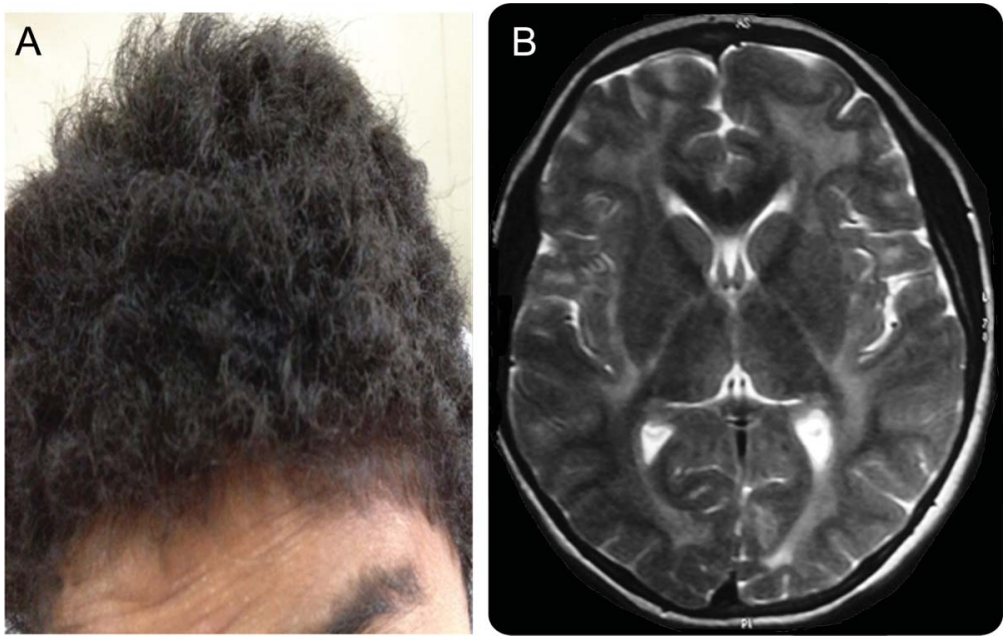

(A) Hair changes. (B) T2-weighted axial MRI brain shows bilateral posterior limbs of internal capsules and deep white matter hyperintensities.

Figure 2 Sural nerve biopsy changes in giant axonal neuropathy

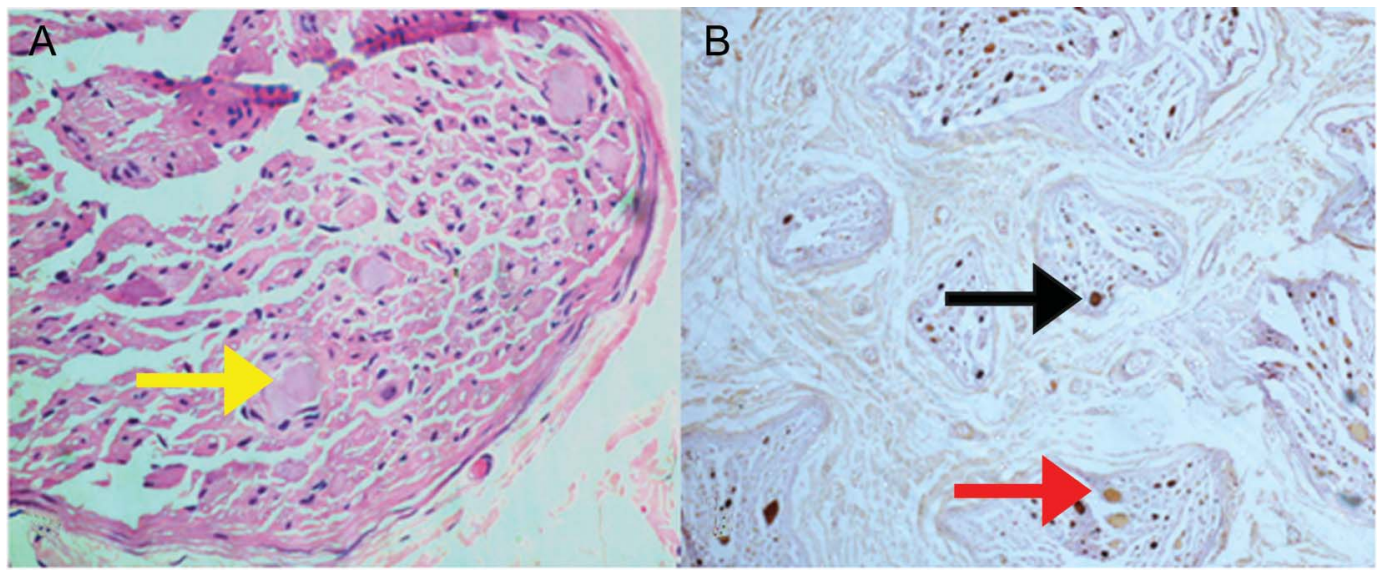

Sural nerve biopsy shows (A) giant axons (yellow arrow) on hematoxylin \& eosin staining ( $\times 200)$, (B) neural intermediate filament immunostaining (arrows; black [normal], red [abnormal], $\times 200$ ).

A 10-year-old girl without consanguinity or neurologic disease in the family presented with an 8- to 9-year history of progressive gait disturbance, incoordination, and impaired hearing and cognition; antenatal and neonatal histories were unremarkable. Salient examination findings were tightly curled scalp hair (figure 1A), impaired cognition and hearing, flaccid quadriparesis, and pancerebellar dysfunction. Salient investigative findings were leukodystrophy on MRI brain (figure 1B), sensorimotor polyneuropathy, and giant axons with aberrant neurofilament immunostaining on sural nerve biopsy (figure 2, A and B). Giant axonal neuropathy is a rare (worldwide 50 families reported) autosomal recessive disorder characterized by gigaxonin gene mutations and disorganization of intermediate filaments. ${ }^{1,2}$ 
Anil Israni, MD, Biswaroop Chakrabarty, DM, Sheffali Gulati, MD, Akbar Mohamed, CH MD, Atin Kumar, MD, Mukund N. Sable, MD, Vaishali Suri, MD

From All India Institute of Medical Sciences, New Delhi, India.

Author contributions: Dr. Israni, Dr. Chakrabarty, and Dr. Akbar worked up the patient and prepared the manuscript under the guidance of Dr. Gulati. Dr. Kumar provided the radiologic inputs. Dr. Sable and Dr. Suri provided the pathologic inputs.

Study funding: No targeted funding reported.

Disclosure: The authors report no disclosures relevant to the manuscript. Go to Neurology.org for full disclosures.

Correspondence to Dr. Gulati: sheffaligulati@gmail.com

1. Kuhlenbaumer G, Timmerman V, Bomont P. Giant axonal neuropathy. Gene Rev 2013 (updated 2012).

2. Mahammad S, Murthy SN, Didonna A, et al. Giant axonal neuropathy-associated gigaxonin mutations impair intermediate filament protein degradation. J Clin Invest 2013;123:1964-1975.

\section{NeuroImages Are Free at www.neurology.org!}

All Neurology ${ }^{\circledR}$ NeuroImages can now be freely accessed on the Neurology Web site. See them at www.neurology.org, where you can also sign up for journal email alerts and check out other online features, including the Resident \& Fellow section, Neurology: Clinical Practice, and the weekly Neurology Podcasts. 


\section{Neurology}

\section{Giant axonal neuropathy: A clinicoradiopathologic diagnosis}

Anil Israni, Biswaroop Chakrabarty, Sheffali Gulati, et al.

Neurology 2014;82;816-817

DOI 10.1212/WNL.0000000000000177

\section{This information is current as of March 3, 2014}

\section{Updated Information \&} Services

\section{References}

Subspecialty Collections

Permissions \& Licensing

Reprints including high resolution figures, can be found at: http://n.neurology.org/content/82/9/816.full

This article cites 1 articles, 0 of which you can access for free at: http://n.neurology.org/content/82/9/816.full\#ref-list-1

This article, along with others on similar topics, appears in the following collection(s):

All Clinical Neurology

http://n.neurology.org/cgi/collection/all_clinical_neurology

Leukodystrophies

http://n.neurology.org/cgi/collection/leukodystrophies

MRI

http://n.neurology.org/cgi/collection/mri

Peripheral neuropathy

http://n.neurology.org/cgi/collection/peripheral_neuropathy

Information about reproducing this article in parts (figures,tables) or in its entirety can be found online at:

http://www.neurology.org/about/about_the_journal\#permissions

Information about ordering reprints can be found online:

http://n.neurology.org/subscribers/advertise

Neurology ${ }^{\circledR}$ is the official journal of the American Academy of Neurology. Published continuously since 1951, it is now a weekly with 48 issues per year. Copyright @ 2014 American Academy of Neurology. All rights reserved. Print ISSN: 0028-3878. Online ISSN: 1526-632X.

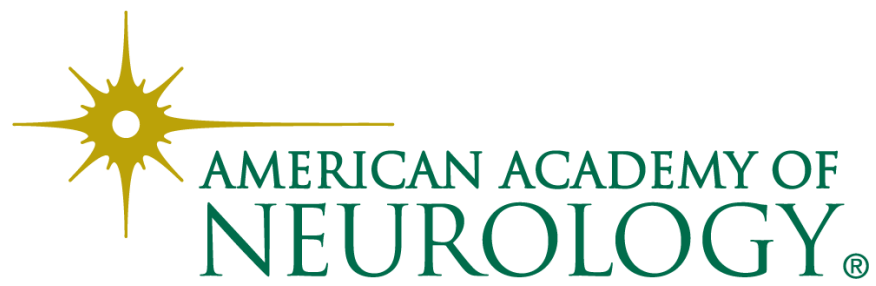

